\title{
Üniversite Öğrencilerinin Facebook Bağlanma Stratejilerinin ve Yaşam Doyumlarının İncelenmesi*
}

\author{
Facebook Connection Strategies and Life Satisfaction of \\ University Students*
}

\begin{abstract}
Ahmet Oğuz AKTÜRK**, Barış EMLEK***, İsmail ÇELİK****
Öz: Bu çalışmanın amacı, üniversite öğrencilerinin Facebook bağlanma stratejileri ve yaşam doyumlarını incelemektir. Çalışma 2014-2015 öğretim yılında yürütülmüş olup, çalışmanın araştırma grubunu 281 üniversite öğrencisi oluşturmuştur. Mevcut durumun betimlenmesinin amaçlandığı bu çalışmada tarama modellerinden ilişkisel tarama modeli kullanılmıştır. Öğrencilerin Facebook bağlanma stratejilerini belirlemek için "Facebook Bağlanma Stratejileri Ölçeği”, yaşam doyumlarını belirlemek için de "Yaşam Doyum Ölçeği” kullanılmıştır. Araştırmadan elde edilen bulgular, öğrencilerin yaşam doyumları ile Facebook bağlanma stratejileri (başlatma, sürdürme ve bilgi arama) arasında pozitif yönde anlamlı bir ilişki olduğunu göstermiştir. Ayrıca araştırma sonuçları, öğrencilerin Facebook bağlanma stratejileri (başlatma, sürdürme ve bilgi arama) ile yaşam doyumlarının öğrenim gördükleri okul türü, bilgisayar sahipliği ve Facebook kullanım süresi değişkenlerine göre anlamlı düzeyde farklılaştığını göstermektedir. Bunun yanı sıra, öğrencilerin Facebook bağlanma stratejilerinin cinsiyet (başlatma, sürdürme ve bilgi arama alt boyutlarında), internet sahipliği (başlatma, sürdürme ve bilgi arama alt boyutlarında), barınma türü (başlatma alt boyutunda) ve geldiği şehir (bilgi arama alt boyutunda) değişkenlerine göre anlamlı düzeyde farklılaştığını göstermektedir.

Anahtar Kelimeler: Facebook bağlanma stratejileri, üniversite öğrencileri, yaşam doyum
\end{abstract}

\begin{abstract}
The purpose of this study is to investigate university students' Facebook connection strategies and life satisfaction. The study was conducted during the 2014-2015 academic year and 281 university students constituted its research group. Relational survey model, one of the survey models, was used in the study, which aimed at describing the current situation. "Facebook Connection Strategies Scale" was used to identify the students' Facebook connection strategies and "Life Satisfaction Scale" was used to determine their life satisfaction. The data obtained from the study indicated a positive and significant correlation between the students' life satisfaction and Facebook connection strategies (initiating, maintaining and information-seeking). Moreover, research findings also indicated that the students' Facebook connection strategies (initiating, maintaining and information-seeking) and life satisfaction varied significantly by the variables of the type of school they attended, computer ownership and duration of their Facebook use. The results also showed that the students' Facebook connection strategies differed significantly according to the variables of gender (in initiating, maintaining and information-seeking subdimensions), internet ownership (in initiating, maintaining and information-seeking sub-dimensions), housing type (in the initiating sub-dimension) and their hometown (in the information-seeking subdimension).
\end{abstract}

Keywords: Facebook connection strategies, university students, life satisfaction

\section{Giriş}

Hızla gelişen teknolojiyle birlikte insanların iletişim alışkanlıklarındaki yenilikler sosyalleşme tutumlarında da hızlı bir değişime neden olmuştur. Bireylerin sosyal çevre edinme alışkanlıkları hayatlarına giren yeni teknolojiler temelinde köklü değişiklikler göstermeye başlamış ve sosyal

\footnotetext{
*Bu makale, 23-26 Nisan 2015 tarihleri arasında Antalya'da düzenlenen "International Conference on Education in Mathematics, Science \& Technology (ICEMST)" de sözlü olarak sunulan bildirinin genişletilmiş halidir.

**Yrd. Doç. Dr., Necmettin Erbakan Üniversitesi, Ereğli Eğitim Fakültesi, Ereğli/Konya-Türkiye, e-posta: aoakturk@konya.edu.tr

***Öğr. Gör., Selçuk Üniversitesi, Çumra MYO, Çumra/Konya-Türkiye, e-posta: bemlek@ selcuk.edu.tr

****Arş. Gör., Necmettin Erbakan Üniversitesi, A.K. Eğitim Fakültesi, Konya-Türkiye, e-posta: icelik@konya.edu.tr
} 
çevre edinme alanlarını değişmiştir (Erkoç ve Erkoç, 2011; Özmen, Aküzüm, Sünkür ve Baysal, 2012; Uslu Karahan, 2007). Bu alanların başında internet ve ona bağlı teknolojiler gelmektedir. Kısa geçmişine rağmen dünya üzerinde geniş bir kullanıma sahip olan internet günümüzün en çok tercih edilen kitle iletişim aracıdır (Echeng ve Usoro, 2017; Koh-Herlong ve Brown, 2017). TCP/IP (Transmission Control Protocol/Internet Protocol) protokolü temelinde birden fazla bilgisayar ağının birbirine bağlanmasıyla oluşan bir ağ (network) sistemi olan internet (İşman, 2011), "ağların ağı" olarak da isimlendirilmektedir (Herbig ve Hale, 1997). Bilgisayarlar arasında kurulmuş olan bu ağın bir sahibi olmadığı gibi; bu ağı işleten, idare ve kontrol eden bir otorite de yoktur (Aktürk, Şahin ve Sünbül, 2008).

İnternet, Web 2.0 araçlarının gelişimiyle birlikte insanları birbiriyle daha fazla bağlantılı hale getirmiş ve sahip olduğu etkileşimli özellikler sayesinde insanların çevrimiçi ortamlarda paylaşımını kolaylaştırarak bilgiye ulaşabilirliğini artırmıştır (Cochrane, 2014; Warschauer ve Grimes, 2007). Web 2.0 kavram, bir konferanstaki beyin firtınas1 oturumunda O'Reilly ve "MediaLive International" tarafindan dile getirilmiştir (O'Reilly, 2005). Ana düşüncesinde "kullanıcının katılımı ile zengin bilgi kaynakları oluşturma" nın olduğu Web 2.0 teknikleri ile inşa edilen web siteleri daha fazla kullanıcı merkezlidir. D'Souza (2006) Web 2.0'1 "ikinci nesil web araçları ya da sosyal yazılımlar" olarak da isimlendirmekte ve Web 2.0 araçlarını "okunabilir ve yazılabilir web" olarak tanımlanmaktadır. Web 2.0 teknolojileri, kullanıc tarafindan üretilen içeriği, kullanılabilirliği ve birlikte çalışlabilirliği vurgulayan internet araçları olarak tanımlanabilir (Karahan ve Roehrig, 2016). Web 2.0 teknolojileri ile oluşturulan uygulamaları sayesinde kullanıcılar internette sadece bilgi bulmakla kalmaz, içeriğe aktif katkıda bulunarak (Lai ve To, 2015) yorumlarını, görüşlerini ve duygularını özgürce ifade edebilirler (Feng, Wang, Yu, Gao ve Wong, 2011). Web 2.0 uygulamalarının erişime açık ve kullanıcı dostu bir ara yüze sahip olması, işbirliğini teşvik etmesi, sosyal etkileşimi ve bilginin paylaşımını kolaylaştırmak üzere tasarlanabilmesinden dolayı (Dietrich, Jones ve Wright, 2008; Orenga-Roglá ve Chalmeta, 2016) daha önce internet kullanım tecrübesi az olan bireyler de bu uygulamalar sayesinde interneti daha sık kullanmaya başlamışlardır. Bu uygulamaların en önemlilerinden biri de sosyal ağlardır.

Her ne kadar sosyal ağ kavramı internet ile birlikte anılsa da, kavram günümüzden çok daha uzun zaman öncesinde de vardır. Çünkü insanlar sosyal varlıklardır ve yaşamını sürdürmek için diğer insanlarla ilişki kurmaları gerekir (Coyle ve Vaughn, 2008). Sosyal ağ kavramını ilk kez 1954 yılında Barnes, bireyin etrafındaki diğer bireylerle olan ilişkilerini tanımlamak için kullanmıştır. Ona göre sosyal ağlar birbirleriyle etkileşim içerisinde olan ve birey için psikolojik öneme sahip diğer bireylerden oluşmaktadır (Can, 2009). Sosyal ağ kavramının sözlük anlamı ise, "bir ya da birden fazla toplumsal ilişkiyle birbirine bağlanmış, dolayısıyla toplumsal bir bağ oluşturan bireyler (daha ender durumlarda ortaklıklar ve roller)" dir (Marshall, 1999). Web 2.0 teknolojilerinin sosyal ağ kavramını internet ortamına taşımasıyla birlikte, bireyler arasında geçmişte var olan ancak somut bir şekilde görülemeyen bağlantılar internet üzerinde daha görünür hale gelmiştir (Korkmaz, 2012). Rheingold (2000), siber uzayda kişisel ilişkiler ağı oluşturmak üzere yeterli sayıda insanın, pozitif insani duygularla, yeterli düzeyde halka açık tartışmalara (elektronik olarak) katılımlarıyla oluşturdukları ağdan meydana gelen sanal toplulukları "sanal cemaatler/topluluklar (virtual communities)" olarak tanımlamaktadır.

Bireylerin sanal ortamda organize olmak suretiyle oluşturdukları sanal topluluklar olarak nitelendirilen sosyal ağ siteleri, bireylerin kendilerini tanıtmak amacıyla bazı kişisel bilgilerini içeren profil sayfaları oluşturabildiği, mevcut arkadaşlıklarını çevrimiçi olarak sürdürebildiği, diğer kullanıcılarla iletişim kurarak yeni arkadaşlar ve sosyal gruplar edinebildiği, çeşitli içerik ve bilgileri (resim, video, doküman gibi) paylaşabildiği ve gelişmiş araçlarla kendi içeriklerini düzenleyebildiği çevrimiçi sanal ortamlardır (Acquisti ve Gross, 2006; Ellison, Steinfield ve Lampe, 2007; Hargittai ve Hsieh, 2010; Joy ve Katherine, 2008; Lenhart ve Madden, 2007). Sosyal ağ siteleri, kendinden önceki teknolojilerin (kişisel web sayfaları gibi) özelliklerini de içine alan teknolojik araçlar bütünü olmasının yanında kullanıcılarının geniş bir sosyal ilişki ağını kurma ve sürdürme yeteneklerini yeni bir bağlamda 
yeniden şekillendirir (Ellison, Steinfield ve Lampe, 2011). Özellikle ergenlik dönemindeki çocuklar ve gençler için arkadaşları ile kurdukları ilişkiler oldukça önemli olmaktadır (West, Lewis ve Currie, 2009). Bu yaş grubundaki bireyler arkadaşları ile fazlaca iletişim kurabilecekleri ortamlar ve paylaşımlarını artıracak yeni arkadaşlıklar arayışındadırlar. Boyd ve Ellison (2007) 'Sosyal A $\breve{g}$ Sitesi' teriminin, genellikle sosyal ă sitesindeki yabancilarla tanışmaya çalışanları değil (bu durum için 'Sosyal A $\breve{g}$ Kurma Sitesi' terimi önerilebilir) çevrimdış1 sosyal ilişkilerini açık bir şekilde ifade etmek ve göstermek için siteyi kullanan bireylerin oluşturduğu bir yapıyı temsil ettiğini savunmaktadırlar.

Günümüzde en çok kullanıcıya sahip olan sosyal ă̆ sitesi Facebook’tur. Facebook, insanların "tanıdıklarıyla iletişim kurmalarını ve hayatlarında olup bitenleri paylaşmalarını" sağlar (Facebook, 2017). 2016 yılı Aralık ayı verilerine göre Facebook'un dünya genelindeki aylık aktif kullanıcı sayısı 1,8 milyar sınırına dayanmıştır (Socialbakers, 2017a). Türkiye' de de Facebook kullanıcılarının sayısı her geçen gün artmaktadır. Türkiye'deki Facebook kullanıcılarının sayısı son 6 ayda \%4 artış göstererek 2016 yılının Aralık ayı itibarıyla 43 milyona ulaşmış ve Facebook kullanıcı sayısı açısından ülkeler sıralamasında 6. sırada yer almasını sağlamıştır (Socialbakers, 2017b). 2004 yılından beri, insanların tanıdıklarıyla iletişim kurmalarını ve bu iletişimlerini sürdürmelerini kolaylaştırıcı yeniliklerle devamlı kendini geliştiren Facebook'un rakiplerinden daha üstün olduğu açıkça görülmektedir (Korkmaz, 2012). Kısa bir süre içinde tüm dünyayı bağlantılı hale getiren Facebook'un, içindeki 42 milyonu aşkın Türk kullanıcısıyla birlikte dünyadaki 1,7 milyara yakın insanın iletişim biçimlerini az ya da çok etkilediği ve büyük ihtimalle bundan sonraki kuşağın da iletişim şeklini belirleyeceği söylenebilir.

Şüphesiz ki bir iletişim aracı olarak kullanıcı sayısı hızla artan ve son zamanların en popüler sosyal ağ sitesi olan Facebook, araştırmacıların ilgisini de üzerine toplamıştır. Facebook'un bu popülerliği nedeniyle araştırmacılar bu sosyal ağ sitesinin niçin, ne kadar ve nasıl kullanıldığını anlamak için birçok araştırma yapmışlardır. Araştırma sonuçları insanların Facebook'u daha çok var olan arkadaşlıklarını çevrimiçi olarak sürdürmek, yeni arkadaşlar edinmek, başka insanlar hakkında bilgi edinmek ve çeşitli içerikleri paylaşmak için kullandıklarını göstertmektedir (Acquisti ve Gross, 2006; Boyd ve Ellison, 2007; Ellison, Steinfield ve Lampe, 2007; Govani ve Pashley, 2005; Hargittai ve Hsieh, 2010; Kobak ve Biçer, 2008; Lampe, Ellison ve Steinfield, 2008; Şener, 2009). Facebook kullanım amaçlarını, sürelerini ve beklentilerini etkileyen başka bir faktörde kullanıcıların yaşamdan beklentileridir (Valenzuela, Park ve Kee, 2009). İnsanların yaşam kalitelerinin ne düzeyde olduğu ve yaşamdan yeterince zevk alıp almadığının internetteki sosyal ağ kullanımını da etkilediği düşünülmektedir.

Yaşam doyumu ve yaşam kalitesinin diğer göstergeleri kişinin çevresiyle ilgili pozitif ya da negatif yönde olabilen genel değerlendirmelerini yansıtır (Scheufele ve Shah, 2000). Araştırmacılar genellikle yaşam doyumunu, öznel iyi oluş veya kişisel memnuniyet olarak ele almaktadırlar (Diener, Emmons, Larsen ve Griffin, 1985). Öznel iyi oluş, bireyin kendi yaşantısını bilişsel ve duygusal olarak değerlendirmesi olarak tanımlanabilir (Tuzgöl Dost, 2007). Yaşam doyumu ise, bireyin kendi mutluluğuyla ilgili kavramlardan öznel iyi oluşun bilişsel yönünü temsil etmektedir (Pavot, Diener, Colvin ve Sandvik, 1991). Yani, bireylerin yaşama ait beklentileri (ne istediği) ile elinde olanları (neye sahip olduğu) karşılaştırmaları sonucunda elde ettikleri bilişsel sonuç yaşam doyumu olarak ifade edilebilir (Özer ve Karabulut, 2003). Mevcut araştırmalar bireylerin yaşam doyumunun kısmen sosyal bağlarla belirlendiğinin altını çizmektedirler (Kahneman ve Krueger, 2006; Valenzuela, Park ve Kee, 2009). Örneğin Topkaya ve Kavas (2015) 1072 üniversite öğrencisi üzerinde yaptıkları bir araştırma sonucunda sosyal desteği yüksek olan öğrencilerin yaşam doyumlarının da yüksek olduğu sonucuna ulaşmışlarıdır. Biz de bu araştırmada diğerlerinden faklı olarak üniversite öğrencilerinin insanları birbirine bağlayan ve sosyal çevre edinme alışkanlıklarında köklü bir değișime neden olan sosyal ağ sitelerinden biri olan Facebook'a bağlanma stratejileri ile yaşam doyumları arasındaki ilişkiyi incelemeyi hedefledik. Bu anlamda bu çalışmanın literatürde önemli bir boşluğu dolduracağı düşünülmektedir. 


\section{Araştırmanın amacı}

$\mathrm{Bu}$ araştırmanın amacı, üniversite öğrencilerinin Facebook bağlanma stratejileri ve yaşam doyumlarını incelemektir. $\mathrm{Bu}$ genel amaç doğrultusunda aşağıda verilen sorulara cevap aranmıştır:

1. Öğrencilerin Facebook bağlanma stratejileri ile yaşam doyumları arasında bir ilişki var midir?

2. Öğrencilerin Facebook bağlanma stratejileri ile yaşam doyumları
a. Cinsiyet,
b. Öğrenim gördükleri okul türü,
c. Bilgisayar sahipliği,
d. İnternet sahipliği,
e. Facebook kullanım süresi,
f. Barınma türü,
g. Geldiği şehir,

değişkenlerine göre farklılaşma göstermekte midir?

\section{Yöntem}

\section{Araştırmanın modeli}

$\mathrm{Bu}$ araştırmada tarama modellerinden "ilişkisel tarama modeli" kullanılmıştır. Tarama modelleri genel olarak bir evrenin kendine özgü özelliklerini ortaya koyabilmek amaciyla yürütülen araştırma modelleridir (Johnson ve Christensen, 2000). İlişkisel tarama ise iki ve daha çok değişken arasındaki etkileşimin varlığını ve miktarını belirlemek için kullanılan bir araştırma modelidir (Karasar, 2006).

\section{Çalışma grubu}

Araştırma 2014-2015 öğretim yılında Konya ili merkezinde bulunan bir üniversitede yürütülmüştür. Çalışmanın araştırma grubunu üniversitenin fakülte ve meslek yüksekokulunda öğrenim görmekte olan 281 öğrenci oluşturmuştur. Çalışma grubuna dair istatistikî bilgiler Tablo 1'de verilmiştir.

Tablo 1

Çalışma Grubunun Demografik Özellikleri

\begin{tabular}{llrr}
\hline Öğrenci Özellikleri & Seçenek & $\mathrm{n}$ & $\mathrm{f}(\%)$ \\
\hline \multirow{2}{*}{ Cinsiyet } & Kadın & 132 & 47,0 \\
& Erkek & 149 & 53,0 \\
\hline \multirow{2}{*}{ Okul Türü } & Fakülte & 144 & 51,2 \\
& Meslek Yüksekokulu & 137 & 48,8 \\
\hline \multirow{2}{*}{ Bilgisayara Sahip } & Var & 257 & 91,5 \\
Olma & Yok & 24 & 8,5 \\
\hline \multirow{2}{*}{ İnternete Sahip Olma } & Var & 259 & 92,2 \\
& Yok & 22 & 7,8 \\
\hline
\end{tabular}

Tablo 1'de verildiği üzere, çalışmaya katılan öğrencilerin \%47'si kadınlardan oluşurken $\% 53$ 'ü de erkeklerden oluşmaktadır. Öğrencilerin öğrenim gördükleri okul türünde ise hemen hemen bir eşitlik söz konusudur. Öğrencilerin \%51,2'si fakültede öğrenim görürken \%48,8'i de meslek yüksekokulunda öğrenim görmektedirler. Çalışma grubu öğrencilerinin \% $\% 91,5$ 'i bilgisayara sahip olduğunu belirtmiştir. Ayrıca araştırmaya katılan öğrencilerin \%92,2'sinin de internet bağlantısına sahip olduğu görülmektedir. Bu oranlar bilgisayar teknolojilerinin hızla yaygınlaştı̆̆ını göstermektedir. 


\section{Veri toplama araçları}

\section{Facebook bağlanma stratejileri ölçeği}

"Facebook Bağlanma Stratejileri Ölçeği (FBSÖ)" Ellison, Steinfield ve Lampe (2011) tarafindan geliştirilen bir ölçektir. Ölçeğin Türkçe uyarlaması Aktürk, Çelik, Şahin ve Deniz (2014) tarafindan yapılarak Türk üniversite öğrencileri üzerinde geçerlik ve güvenirliği belirlenmiştir. Uyarlanan ölçek, 5 dereceli Likert tipinde olup; üç faktör ve 12 maddeden oluşmaktadır. Ölçeğin ilk faktörü "Başlatma" olarak isimlendirilmekte olup, Facebook'un yabancılarla tanışmak için kullanılması davranışlarını tanımlamaktadır. Bu faktörden alınan yüksek puanlar, bireyin Facebook'u daha çok yeni insanlarla tanışmak, onların profillerine göz atmak, onlarla iletişim kurmak, arkadaş olmak veya onlarla şahsen tanışmak için kullanıldığını göstermektedir. Ölçeğin ikinci faktörü olan "Sürdürme" faktörü ise, Facebook'un yakın arkadaşlar ile ilgili arama yapma, onlarla iletişime geçme, onları arkadaş olarak ekleme ve onlarla Facebook aracılığıyla görüşme amacıyla kullanılması davranışlarını içerir. Bu faktörden alınan yüksek puanlar, bireyin Facebook'u yakın arkadaşları ile ilgili arama yapma, onlarla iletişime geçme ve onları arkadaş olarak ekleme için kullanıldığını göstermektedir. Ölçeğin üçüncü ve son faktörü olan "Bilgi arama" faktörü ise, Facebook'un birisi hakkında daha fazla bilgi edinilmesi amacıyla kullanılması ile ilgili olan bazı davranışları tanımlamaktadır. $\mathrm{Bu}$ faktörden alınan yüksek puanlar, bireyin Facebook'u daha çok sosyal hayatta karşılaştığı ancak tanımadığı birisi hakkında bilgi edinmek, sınıftaki akranları ve etrafında yaşayan diğer bireyler hakkında daha fazla bilgi elde etmek için kullanıldığını göstermektedir. Ölçekten alınan puanların değerlendirilmesi faktör bazında yapılmaktadır. Ölçeğin faktörlerindeki tüm maddeler olumlu olup ters yönde kodlanan madde bulunmamaktadır. Uyarlanan 12 maddelik ölçeğin Cronbach Alpha iç tutarlık katsayıları birinci faktör için 0,80, ikinci faktör için 0,89 , üçüncü faktör için 0,82 olarak hesaplanmıştır (Aktürk ve diğerleri, 2014). Bu araştırmada, veri toplama aracı olarak kullanılan Facebook Bağlanma Stratejileri Ölçeği'nin araştırmanın çalışma gurubu üzerinde yapılan güvenirlik hesaplanması sonucunda Cronbach Alpha iç tutarlık katsayıları sırasıyla, birinci faktör için 0,71 , ikinci faktör için 0,80 , üçüncü faktör için 0,90 olarak hesaplanmıştır.

\section{Yaşam doyum ölçeği}

Öğrencilerin yaşam doyum düzeylerini belirlemek için "Yaşam Doyum Ölçeği” kullanılmıştır. Ölçek Diener, Emmons, Laresen ve Griffin (1985) tarafindan geliştirilmiş olup, Türkçe'ye Köker (1991) tarafından uyarlanmıştır. Ölçek toplam 5 maddeden oluşmaktadır. Likert tipi bir ölçek olan Yaşam Doyum Ölçeği'nin puanlaması (1) Hiç Katılmıyorum ile (7) Tamamen Katılıyorum arasında değişen 7 dereceli bir skala ile yapılmaktadır. Ölçeğin test-tekrar test güvenirlik katsayısı 0,85 olarak saptanmıştır. $\mathrm{Bu}$ araştırma kapsamında kullanılan Yaşam Doyum Ölçeği'nin araştırmanın çalışma gurubu üzerinde yapılan güvenirlik hesaplanması sonucunda Cronbach Alpha iç tutarlık katsayısı 0,82 bulunmuştur.

\section{Verilerin analizi}

Araştırma kapsamında toplanan verileri analiz etmeden önce, verilerin normal dağılım gösterip göstermediği incelenmiştir. $\mathrm{Bu}$ amaçla öncelikle ölçeklerden elde edilen verilerin normal dağılıma uygunluğuna Kolmogorov-Smirnov Testi ile bakılmıştır. Gerçekleştirilen Kolmogorov-Smirnov Testi sonucunda Facebook Bağlanma Stratejileri Ölçeği'nin tüm alt boyutları $\left(\mathrm{K}-\mathrm{S}_{\text {Başlatma }}=0,092, \mathrm{~K}-\mathrm{S}_{\text {Sürdürme }}=0,109, \mathrm{~K}-\mathrm{S}_{\text {Bilgi arama }}=0,143\right)$ ve Yaşama Doyum Ölçeği $\left(\mathrm{K}-\mathrm{S}_{\text {Yaşam doyum }}=0,114\right)$ için bulunan $\mathrm{p}$ değerinin $0,05^{\prime}$ den küçük olduğu görülmüş̧ür. Ancak, ölçeklere ait çarpıklık ve basıklık katsayılarının -1 ile +1 sınırları içinde kalması durumunda ölçeklerden alınan puanların normal dağılıma uygun olduğu söylenebilir (Huck, 2012; Leech, Barrett ve Morgan, 2005). Bu amaçla ölçeklerden alınan toplam puanların dağılımları üzerinde çarpıklık ve basıklık değerleri incelenmiş ve hesaplama sonucunda elde edilen değerler Tablo 2 'de verilmiştir. 
Tablo 2

Ölçeklere Ait Çarpıklık ve Basıklık Katsayıları

\begin{tabular}{llcc}
\hline Ölçek & & Çarpıklık & Basılılk \\
\hline Facebook & Başlatma &,- 042 &,- 595 \\
Bağlanma & Sürdürme &,- 033 &,- 817 \\
Stratejileri & Bilgi arama &,- 497 &,- 702 \\
\hline \multicolumn{2}{l}{ Yaşam Doyum } &,- 430 &,- 643 \\
\hline
\end{tabular}

Tablo 1'de verilen değerler incelendiğinde, Facebook Bağlanma Stratejileri Ölçeği'nin her bir faktörü ve Yaşam Doyum Ölçeği için hesaplanan çarpıklık ve basıklık katsayılarının -1 ile +1 sınırları içinde kalması, ölçeklerden alınan puanların normal dağılım sergilediğini göstermektedir (Huck, 2012; Leech, Barrett ve Morgan, 2005). Bunun sonucunda ölçeklerden elde edilen veriler üzerinde parametrik testlerin kullanılmasına karar verilmiştir. Bu kapsamda ölçeklerden toplanan verilerin analizinde betimsel istatistikler, korelasyon analizi, ikili gruplar arasındaki farklılıkları belirlemek için bağımsız örneklem t-testi ve ikiden fazla olan gruplar arasındaki farklılıkları belirlemek için de tek yönlü ANOVA testi analizi kullanılmıştır. ANOVA testinde gruplar arasındaki farklar Scheffe testi ile incelenmiştir.

\section{Bulgular}

\section{Facebook bağlanma stratejileri ve yașam doyum arasındaki ilișki}

Öğrencilerin Facebook bağlanma stratejileri ile yaşam doyumları arasındaki ilişkinin incelenmesi için Pearson Momentler Çarpım Korelâsyonu kullanılmıştır. Analiz sonucunda elde edilen değerler Tablo 3 'te verilmiştir.

Tablo 3

Facebook Bağlanma Stratejileri ve Yaşam Doyum Arasındaki İlişki

\begin{tabular}{lcccc}
\hline \multirow{2}{*}{ Ölçek } & \multicolumn{2}{c}{ Facebook Bağlanma Stratejileri } & \multirow{2}{*}{$\begin{array}{c}\text { Yaşam } \\
\text { Doyum }\end{array}$} \\
\cline { 2 - 3 } & Başlatma & Sürdürme & Bilgi Arama & \\
Başlatma & - & & & \\
Sürdürme &, $698^{* *}$ & - & & \\
Bilgi arama &, $310^{* *}$ &, $348^{* *}$ & - & \\
Yaşam doyum &, $131^{*}$ &, $191^{* *}$ &, $396^{* *}$ & - \\
\hline **: Korelasyon 0.01 düzeyinde anlamlı (2-yönlü) & & \\
*: Korelesyon 0.05 düzeyinde anlamlı (2-yönlü) & &
\end{tabular}

Yaşam doyum ile Facebook bağlanma stratejilerinin tüm alt boyutları pozitif yönde anlamlı bir ilişki göstermiştir (Tablo 3). Bu sonuç bize öğrencilerin Facebook'un farklı kullanımları (başlatma, sürdürme ve bilgi arama) ile yaşam doyumları arasında bir ilişkinin olduğunu ve öğrencilerin Facebook'u bu amaçlar (başlatma, sürdürme ve bilgi arama) için kullanımları arttıkça yaşam doyumlarının da arttı̆̆ını göstermektedir. Bunun yanı sıra Facebook bağlanma stratejileri ölçeğinin bütün alt boyutları arasında pozitif yönde anlamlı ilişkilerin olduğu Tablo 3'ten görülmektedir.

\section{Cinsiyet açısından Facebook bağlanma stratejileri ve yaşam doyum}

Öğrencilerin cinsiyetlerine göre Facebook bağlanma stratejileri ve yaşam doyumları arasındaki farklılaşma durumları bağımsız örneklem t-testi ile analiz edilmiştir. Analiz sonucunda elde edilen değerler Tablo 4'te verilmiștir.

Tablo 4'te verilen değerler incelendiğinde, erkek ve k1z öğrencilerin Facebook bağlanma stratejileri ölçeğinin "Başlatma" $(\mathrm{t}=-6,330 ; p<0,001)$ ve "Sürdürme" (t=-5,477; $p<0,001)$ alt boyutlarından aldıkları puanlar arasında cinsiyet açısından anlamlı bir farklılık vardır. Ölçeğin bir diğer alt boyutu olan "Bilgi arama" $(\mathrm{t}=-1,749 ; p>0,05)$ puanlarında ise cinsiyet açısından anlamlı bir farklılık yoktur. Bu sonuçlara göre erkek öğrencilerin $(\bar{X}=15,28)$ 
kız öğrencilere $(\bar{X}=12,11)$ göre Facebook'u yeni insanlarla tanışmak için daha fazla kullandığını göstermektedir. Benzer şekilde yine erkek öğrencilerin $(\bar{X}=12,47)$ kız öğrencilere $(\bar{X}=9,89)$ göre Facebook'u daha çok yakın arkadaşlıkları sürdürme amaçlı kullandıklarını göstermektedir.

Tablo 4

Cinsiyete Göre Facebook Bağlanma Stratejileri ve Yaşam Doyum

\begin{tabular}{|c|c|c|c|c|c|c|}
\hline Ölçek & Cinsiyet & $\mathrm{N}$ & $\bar{X}$ & SD & $\mathrm{t}$ & $\mathrm{p}$ \\
\hline & Kiz & 132 & 12,11 & 4,208 & \multirow{2}{*}{$-6,330$} & \multirow{2}{*}{$<0,001$} \\
\hline & Erkek & 149 & 15,28 & 4,152 & & \\
\hline 8 言 : & $\mathrm{K}_{1 \mathrm{z}}$ & 132 & 9,89 & 3,976 & \multirow{2}{*}{$-5,477$} & \multirow{2}{*}{$<0,001$} \\
\hline $\bar{E}$ & Erkek & 149 & 12,47 & 3,919 & & \\
\hline \multirow{2}{*}{ Bilgi arama } & $\mathrm{K} 1 \mathrm{z}$ & 132 & 10,43 & 3,396 & \multirow{2}{*}{$-1,749$} & \multirow{2}{*}{,081 } \\
\hline & Erkek & 149 & 11,17 & 3,685 & & \\
\hline \multirow{2}{*}{ Yaşam doyum } & $\mathrm{K}_{1 \mathrm{z}}$ & 132 & 22,41 & 6,874 & \multirow{2}{*}{,- 051} & \multirow{2}{*}{,959 } \\
\hline & Erkek & 149 & 22,45 & 6,401 & & \\
\hline
\end{tabular}

Diğer yandan yaşam doyum ölçeğinden alınan puanlar incelendiğinde ise, cinsiyet açısından erkek ve kız ögrencilerin yaşam doyumları arasında anlamlı bir farklılık yoktur ( $\mathrm{t}=-$ $, 051 ; p>0,05)$.

\section{Okul türü açısından Facebook bağlanma stratejileri ve yaşam doyum}

Öğrencilerin öğrenim gördükleri okul türüne göre Facebook bağlanma stratejileri ve yaşam doyumları arasındaki farklılaşma durumları bağımsız örneklem t-testi ile analiz edilmiş olup analiz sonuçları Tablo 5'te verilmiştir.

Tablo 5

Okul Türüne Göre Facebook Bağlanma Stratejileri ve Yaşam Doyum

\begin{tabular}{|c|c|c|c|c|c|c|c|}
\hline Ölçek & & Okul Türü & $\mathrm{N}$ & $\bar{X}$ & SD & $\mathrm{t}$ & $\mathrm{p}$ \\
\hline \multirow{6}{*}{ 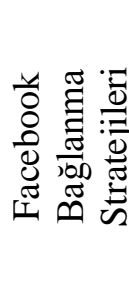 } & \multirow{2}{*}{ Başlatma } & Fakülte & 144 & 12,49 & 4,744 & \multirow{2}{*}{5,259} & \multirow{2}{*}{$<0,001$} \\
\hline & & Meslek & 137 & 15,15 & 3,694 & & \\
\hline & \multirow{2}{*}{ Sürdürme } & Fakülte & 144 & 10,08 & 4,372 & \multirow{2}{*}{5,073} & \multirow{2}{*}{$<0,001$} \\
\hline & & Meslek & 137 & 12,49 & 3,507 & & \\
\hline & \multirow{2}{*}{ Bilgi arama } & Fakülte & 144 & 9,99 & 3,707 & \multirow{2}{*}{4,142} & \multirow{2}{*}{$<0,001$} \\
\hline & & Meslek & 137 & 11,70 & 3,196 & & \\
\hline \multirow{2}{*}{\multicolumn{2}{|c|}{ Yaşam doyum }} & Fakülte & 144 & 21,61 & 7,012 & \multirow{2}{*}{2,150} & \multirow{2}{*}{,032 } \\
\hline & & Meslek & 137 & 23,29 & 6,079 & & \\
\hline
\end{tabular}

Tablo 5'ten de görüldüğü üzere, öğrencilerin Facebook bağlanma stratejileri ölçeğinin tüm alt boyutlarından ["Başlatma" ( $\mathrm{t}=5,259 ; p<0,001)$, "Sürdürme" $(\mathrm{t}=5,073 ; p<0,001)$ ve "Bilgi arama" (t=4,142; $p<0,001)]$ aldıkları puanlar arasında öğrenim gördükleri okul türü açısından anlamlı bir farklılık vardır. Bu sonuçlara göre üniversitenin meslek yüksekokullarında öğrenim gören öğrencilerin $(\bar{X}=15,15)$ fakültelerinde öğrenim gören öğrencilere $(\bar{X}=12,49)$ göre Facebook'u yeni insanlarla tanışmak ve bir ilişkiyi başlatmak için daha fazla kullandığını göstermektedir. Benzer şekilde yine üniversitenin meslek yüksekokullarında öğrenim gören öğrencilerin $(\bar{X}=12,49)$ fakültelerinde öğrenim gören öğrencilere $(\bar{X}=10,08)$ göre Facebook'u daha çok yakın arkadaşlıkları sürdürme amaçlı kullandıklarını göstermektedir. Facebook'un diğer insanlar hakkında daha fazla bilgi edinmek amaciyla kullanımı konusunda da üniversitenin meslek yüksekokullarında öğrenim gören öğrencilerin $(\bar{X}=11,70)$ fakültelerinde öğrenim gören öğrencilere ( $\bar{X}=9,99)$ göre Facebook'u daha fazla kullandığı görülmektedir. 
Diğer yandan yaşam doyum ölçeğinden alınan puanlar incelendiğinde ise, öğrenim görülen okul türü açısından üniversitelerin meslek yüksekokullarında öğrenim gören öğrenciler ile fakültelerinde öğrenim gören öğrencilerin yaşam doyumları arasında anlamlı bir farklılık vardır $(\mathrm{t}=2,150 ; p<0,05)$. Bu sonuç üniversitenin meslek yüksekokullarında öğrenim gören öğrencilerin $(\bar{X}=23,29)$ yaşam doyumlarının fakültelerinde öğrenim gören öğrencilerin $(\bar{X}=21,61)$ yaşam doyumlarından daha yüksek olduğunu göstermektedir.

\section{Bilgisayar sahipliği açısından Facebook bağlanma stratejileri ve yaşam doyum}

Öğrencilerin bilgisayar sahipliğine göre Facebook bağlanma stratejileri ve yaşam doyumları arasındaki farklılaşma durumları bağımsız örneklem t-testi ile analiz edilmiş olup analiz sonuçları Tablo 6' da verilmiştir.

Tablo 6

Bilgisayar Sahipliğine Göre Facebook Bağlanma Stratejileri ve Yaşam Doyum

\begin{tabular}{|c|c|c|c|c|c|c|c|}
\hline Ölçek & & Bilgisayar & $\mathrm{N}$ & $\bar{X}$ & SD & $\mathrm{t}$ & $\mathrm{p}$ \\
\hline \multirow{6}{*}{ 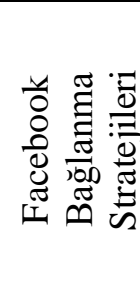 } & \multirow{2}{*}{ Başlatma } & Var & 257 & 14,00 & 4,400 & \multirow{2}{*}{$-2,609$} & \multirow{2}{*}{,010 } \\
\hline & & Yok & 24 & 11,54 & 4,578 & & \\
\hline & \multirow{2}{*}{ Sürdürme } & Var & 257 & 11,39 & 4,157 & \multirow{2}{*}{$-1,817$} & \multirow{2}{*}{,048 } \\
\hline & & Yok & 24 & 9,79 & 3,799 & & \\
\hline & \multirow{2}{*}{ Bilgi arama } & Var & 257 & 11,07 & 3,498 & \multirow{2}{*}{$-3,853$} & \multirow{2}{*}{$<0,001$} \\
\hline & & Yok & 24 & 8,21 & 3,270 & & \\
\hline \multirow{2}{*}{\multicolumn{2}{|c|}{ Yaşam doyum }} & Var & 257 & 22,82 & 6,616 & \multirow{2}{*}{$-3,294$} & \multirow{2}{*}{,001 } \\
\hline & & Yok & 24 & 18,25 & 5,067 & & \\
\hline
\end{tabular}

Tablo 6' da verilen değerler incelendiğinde, bilgisayar sahipliği açısından bilgisayarı olan öğrenciler ile bilgisayarı olmayan öğrencilerin Facebook bağlanma stratejileri puanları ["Başlatma" ( $\mathrm{t}=-2,609 ; p<0,05)$, "Sürdürme" $(\mathrm{t}=-1,817 ; p<0,05)$ ve "Bilgi arama" $(\mathrm{t}=-3,853$; $p<0,001)]$ arasında anlamlı bir farklı1ık vardır. Bu sonuçlara göre bilgisayarı olan öğrencilerin $(\bar{X}=14,00)$ bilgisayarı olmayan öğrencilere $(\bar{X}=11,54)$ göre Facebook'u yeni insanlarla tanışmak ve bir ilişkiyi başlatmak için daha fazla kullandığını göstermektedir. Benzer şekilde yine bilgisayarı olan öğrencilerin $(\bar{X}=11,39)$ bilgisayarı olmayan öğrencilere $(\bar{X}=9,79)$ göre Facebook'u daha çok yakın arkadaşlıkları sürdürme amaçlı kullandıklarını göstermektedir. Facebook' un diğer insanlar hakkında daha fazla bilgi edinmek amacıyla kullanımı konusunda da bilgisayarı olan öğrencilerin $(\bar{X}=11,07)$ bilgisayarı olmayan öğrencilere $(\bar{X}=8,21)$ göre Facebook'u daha fazla kullandığı görülmektedir.

Diğer yandan yaşam doyum ölçeğinden alınan puanlar incelendiğinde ise, bilgisayar sahipliği açısından bilgisayarı olan öğrenciler ile bilgisayarı olmayan öğrencilerin yaşam doyumları arasında anlamlı bir farklılık vardır $(\mathrm{t}=-3,294 ; p<0,05)$. Bu sonuç bilgisayarı olan öğrencilerin $(\bar{X}=22,82)$ yaşam doyumlarının bilgisayarı olmayan öğrencilerin $(\bar{X}=18,25)$ yaşam doyumlarından daha yüksek olduğunu göstermektedir.

\section{İnternet sahipliği açısından Facebook bağlanma stratejileri ve yaşam doyum}

Öğrencilerin internet bağlantısına sahip olup olmamasına göre Facebook bağlanma stratejileri ve yaşam doyumları arasındaki farklılaşma durumları bağımsız örneklem t-testi ile analiz edilmiş olup analiz sonuçları Tablo 7'de verilmiştir.

Tablo 7'den de görüldüğü üzere, internet sahipliği açısından internet bağlantısı olan öğrenciler ile internet bağlantısı olmayan öğrencilerin Facebook bağlanma stratejileri puanları ["Başlatma" ( $\mathrm{t}=-2,379 ; p<0,05)$, "Sürdürme" $(\mathrm{t}=-2,967 ; p<0,05)$ ve "Bilgi arama" $(\mathrm{t}=-4,228$; $p<0,001)$ ] arasında anlamlı bir farklılık vardır. $\mathrm{Bu}$ sonuçlara göre internet bağlantısı olan öğrencilerin $(\bar{X}=13,97)$ internet bağlantısı olmayan öğrencilere $(\bar{X}=11,64)$ göre Facebook'u yeni insanlarla tanışmak ve bir ilişkiyi başlatmak için daha fazla kullandığını göstermektedir. 
Benzer şekilde yine internet bağlantısı olan öğrencilerin $(\bar{X}=11,47)$ bilgisayarı olmayan öğrencilere $(\bar{X}=8,77)$ göre Facebook'u daha çok yakın arkadaşlıkları sürdürme amaçlı kullandıklarını göstermektedir. Facebook'un diğer insanlar hakkında daha fazla bilgi edinmek amacıyla kullanımı konusunda da internet bağlantısı olan öğrencilerin $(\bar{X}=11,01)$ internet bağlantısı olmayan öğrencilere $(\bar{X}=8,68)$ göre Facebook'u daha fazla kullandığı görülmektedir. Ancak, öğrencilerin internet bağlantısına sahip olup olmama durumlarının yaşam doyumlarında bir farklılığa neden olmadığı görülmektedir.

Tablo 7

İnternet Sahipliğine Göre Facebook Bağlanma Stratejileri ve Yaşam Doyum

\begin{tabular}{|c|c|c|c|c|c|c|c|}
\hline Ölçek & & İnternet & $\mathrm{N}$ & $\bar{X}$ & SD & $\mathrm{t}$ & $\mathrm{p}$ \\
\hline \multirow{6}{*}{ 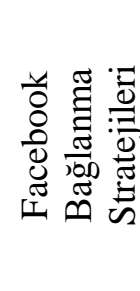 } & \multirow{2}{*}{ Başlatma } & Var & 259 & 13,97 & 4,466 & \multirow{2}{*}{$-2,379$} & \multirow{2}{*}{,018 } \\
\hline & & Yok & 22 & 11,64 & 3,861 & & \\
\hline & \multirow{2}{*}{ Sürdürme } & Var & 259 & 11,47 & 4,107 & \multirow{2}{*}{$-2,967$} & \multirow{2}{*}{,003 } \\
\hline & & Yok & 22 & 8,77 & 3,854 & & \\
\hline & \multirow{2}{*}{ Bilgi arama } & Var & 259 & 11,01 & 3,594 & \multirow{2}{*}{$-4,228$} & \multirow{2}{*}{$<0,001$} \\
\hline & & Yok & 22 & 8,68 & 2,358 & & \\
\hline \multirow{2}{*}{\multicolumn{2}{|c|}{ Yaşam doyum }} & Var & 259 & 22,62 & 6,592 & \multirow{2}{*}{$-1,666$} & \multirow{2}{*}{,097 } \\
\hline & & Yok & 22 & 20,18 & 6,631 & & \\
\hline
\end{tabular}

Facebook kullanım süresi açısından Facebook bağlanma stratejileri ve yaşam doyum

Öğrencilerin günlük Facebook kullanım sürelerine göre Facebook bağlanma stratejileri ve yaşam doyumları arasındaki farklılaşma durumları bağımsız örneklem t-testi ile analiz edilmiş olup analiz sonuçları Tablo 8' de verilmiştir.

Tablo 8

Facebook Kullanım Süresine Göre Facebook Bağlanma Stratejileri ve Yaşam Doyum

\begin{tabular}{|c|c|c|c|c|c|c|c|}
\hline Ölçek & & $\begin{array}{l}\text { Günlük Facebook } \\
\text { Kullanım Süresi }\end{array}$ & $\mathrm{N}$ & $\overline{\mathrm{X}}$ & SD & $\mathrm{t}$ & $\mathrm{p}$ \\
\hline \multirow{6}{*}{ 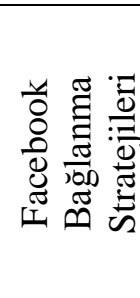 } & \multirow{2}{*}{ Başlatma } & 1 saatten az & 209 & 13,31 & 4,503 & \multirow{2}{*}{$-3,147$} & \multirow{2}{*}{,002 } \\
\hline & & 1 saatten fazla & 72 & 15,19 & 4,044 & & \\
\hline & \multirow{2}{*}{ Sürdürme } & 1 saatten az & 209 & 10,86 & 4,305 & \multirow{2}{*}{$-3,119$} & \multirow{2}{*}{,002 } \\
\hline & & 1 saatten fazla & 72 & 12,42 & 3,410 & & \\
\hline & \multirow{2}{*}{ Bilgi arama } & 1 saatten az & 209 & 10,31 & 3,551 & \multirow{2}{*}{$-4,246$} & \multirow{2}{*}{$<0,001$} \\
\hline & & 1 saatten fazla & 72 & 12,32 & 3,184 & & \\
\hline \multirow{2}{*}{\multicolumn{2}{|c|}{ Yaşam doyum }} & 1 saatten az & 209 & 21,93 & 6,739 & \multirow{2}{*}{$-2,162$} & \multirow{2}{*}{, 031} \\
\hline & & 1 saatten fazla & 72 & 23,88 & 6,058 & & \\
\hline
\end{tabular}

Tablo 8'de verilen değerler incelendiğinde, günlük Facebook kullanım süresi açısından Facebook'u günde 1 saatten az kullanan öğrenciler ile Facebook'u günde 1 saatten fazla kullanan öğrencilerin Facebook bağlanma stratejileri puanları ["Başlatma" $(\mathrm{t}=-3,147 ; p<0,05)$, "Sürdürme" ( $\mathrm{t}=-3,119 ; p<0,05)$ ve "Bilgi arama" $(\mathrm{t}=-4,246 ; p<0,001)]$ arasinda anlamlı bir farklılık vardır. Bu sonuçlara göre Facebook'u günde 1 saatten fazla kullanan öğrencilerin $(\bar{X}=15,19)$ Facebook'u günde 1 saatten az kullanan öğrencilere $(\bar{X}=13,31)$ göre Facebook'u yeni insanlarla tanışmak ve bir ilişkiyi başlatmak için daha fazla kullandığını göstermektedir. Benzer şekilde yine göre Facebook'u günde 1 saatten fazla kullanan öğrencilerin ( $\bar{X}=12,42$ ) Facebook'u günde 1 saatten az kullanan öğrencilere $(\bar{X}=10,86)$ göre Facebook'u daha çok yakın arkadaşlıkları sürdürme amaçlı kullandıklarını göstermektedir. Facebook'un diğer insanlar hakkında daha fazla bilgi edinmek amacıyla kullanımı konusunda da Facebook'u günde 
1 saatten fazla kullanan öğrencilerin $(\bar{X}=12,32)$ Facebook'u günde 1 saatten az kullanan öğrencilere $(\bar{X}=10,31)$ göre Facebook'u daha fazla kullandığı görülmektedir.

Diğer yandan yaşam doyum ölçeğinden alınan puanlar incelendiğinde ise, Facebook kullanım süresi açısından Facebook'u günde 1 saatten fazla kullanan öğrenciler ile Facebook'u günde 1 saatten az kullanan öğrencilerin yaşam doyumları arasında anlamlı bir farklılık vardır $(\mathrm{t}=-2,162 ; p<0,05)$. Bu sonuç, Facebook'u günde 1 saatten fazla kullanan öğrencilerin $(\bar{X}=23,88)$ yaşam doyumlarının Facebook'u günde 1 saatten az kullanan öğrencilerin $(\bar{X}=21,93)$ yaşam doyumlarından daha yüksek olduğunu göstermektedir.

\section{Barınma türü açısından Facebook bağlanma stratejileri ve yaşam doyum}

Öğrencilerin barınma türlerine göre Facebook bağlanma stratejileri ve yaşam doyumları arasındaki farkın istatistiksel olarak anlamlı olup olmadığı tek yönlü varyans analizi (F testi) ile analiz edilmiş olup analiz sonuçları Tablo 9'da verilmiştir.

Tablo 9

Facebook Bağlanma Stratejileri ve Yaşam Doyumun Barınma Türü Açısından Analiz Sonuçları

\begin{tabular}{|c|c|c|c|c|c|c|c|c|}
\hline Ölçek & & $\begin{array}{l}\text { Barınma } \\
\text { Türü }\end{array}$ & $\mathrm{N}$ & $\bar{X}$ & $\mathrm{SD}$ & $\mathrm{F}$ & $\mathrm{p}$ & Fark (Scheffe) \\
\hline \multirow{9}{*}{ 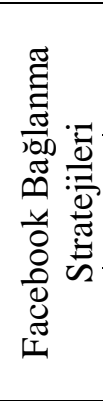 } & & Aile ile & 109 & 12,72 & 4,305 & \multirow{3}{*}{5,262} & \multirow{3}{*}{,006 } & \multirow{3}{*}{$\begin{array}{c}\text { Arkadaş ile }>\text { Aile ile } \\
\text { Yurt }>\text { Aile ile }\end{array}$} \\
\hline & Başlatma & Yurt & 111 & 14,41 & 4,517 & & & \\
\hline & & Arkadaş ile & 61 & 14,57 & 4,322 & & & \\
\hline & \multirow{3}{*}{ Sürdürme } & Aile ile & 109 & 10,90 & 4,139 & \multirow{3}{*}{,796 } & \multirow{3}{*}{,452 } & \\
\hline & & Yurt & 111 & 11,36 & 3,777 & & & \\
\hline & & Arkadaş ile & 61 & 11,70 & 4,769 & & & \\
\hline & \multirow{3}{*}{ Bilgi arama } & Aile ile & 109 & 10,83 & 3,783 & \multirow{3}{*}{2,884} & \multirow{3}{*}{, 058} & \\
\hline & & Yurt & 111 & 11,31 & 3,400 & & & \\
\hline & & Arkadas ile & 61 & 9,95 & 3,339 & & & \\
\hline \multirow{3}{*}{\multicolumn{2}{|c|}{ Yaşam doyum }} & Aile ile & 109 & 23,18 & 6,928 & \multirow{3}{*}{1,652} & \multirow{3}{*}{,193 } & \\
\hline & & Yurt & 111 & 22,32 & 6,423 & & & \\
\hline & & Arkadas ile & 61 & 21,28 & 6,309 & & & \\
\hline
\end{tabular}

Öğrencilerin Facebook bağlanma stratejileri ölçeğinden aldıkları puanlara bakıldığında ölçeğin sadece "Başlatma" alt boyutundan aldıkları puanlar $\left[\mathrm{F}_{(2,278)}=5,262 ; p<0,05\right]$ arasında gruplar açısından istatistiksel olarak anlamlı bir farklılığın olduğu görülmektedir (Tablo 9). Facebook bağlanma stratejileri ölçeğinin "Başlatma" alt boyutunda temel etkinin hangi değişkenden geldiğini belirlemek amacıyla Scheffe testi uygulanmıştır. Scheffe testi sonuçlarına göre, Facebook bağlanma stratejileri ölçeğinin "Başlatma" alt boyutunda çıkan farkın barınma türü "Arkadaş ile" olan öğrenciler ile barınma türü "Aile ile" ve barınma türü "Yurt" olan öğrenciler ile barınma türü "Aile ile" olan öğrencilerden kaynaklandığı görülmektedir. Bu sonuca göre arkadaşı ile birlikte veya yurtta kalan öğrencilerin ailesi ile birlikte kalan öğrencilere göre Facebook'u yeni insanlarla tanışmak ve bir ilişkiyi başlatmak için daha fazla kullandığını göstermektedir.

Öğrencilerin yaşam doyum puanlarına $\left[\mathrm{F}_{(2,278)}=1,652 ; p>0,05\right]$ bakıldığında ise gruplar açısından yaşam doyum puanları arasında istatistiksel olarak anlamlı bir fark yoktur (Tablo 9).

\section{Geldiği şehir açısından Facebook bağlanma stratejileri ve yaşam doyum}

Öğrencilerin geldiği şehre göre Facebook bağlanma stratejileri ve yaşam doyumları arasındaki farkın istatistiksel olarak anlamlı olup olmadığı varyans analizi (F testi) ile analiz edilmiş olup analiz sonuçları Tablo 10' da verilmiştir. 
Tablo 10

Facebook Bağlanma Stratejileri ve Yaşam Doyumun Geldiği Şehir Açısından Analiz Sonuçları

\begin{tabular}{|c|c|c|c|c|c|c|c|c|}
\hline Ölçek & & $\begin{array}{l}\text { Geldiği } \\
\text { Şehir }\end{array}$ & $\mathrm{N}$ & $\bar{X}$ & $\mathrm{SD}$ & $\mathrm{F}$ & $\mathrm{p}$ & Fark (Scheffe) \\
\hline \multirow{9}{*}{ 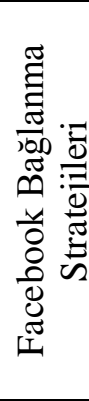 } & \multirow{3}{*}{ Başlatma } & Büyük & 58 & 14,035 & 3,77882 & \multirow{3}{*}{,137 } & \multirow{3}{*}{,872 } & \\
\hline & & Orta & 187 & 13,695 & 4,67643 & & & \\
\hline & & Küçük & 36 & 13,889 & 4,41929 & & & \\
\hline & \multirow{3}{*}{ Sürdürme } & Büyük & 58 & 11,397 & 3,81566 & \multirow{3}{*}{,087 } & \multirow{3}{*}{,916 } & \\
\hline & & Orta & 187 & 11,257 & 4,25003 & & & \\
\hline & & Küçük & 36 & 11,028 & 4,20534 & & & \\
\hline & \multirow{3}{*}{ Bilgi arama } & Büyük & 58 & 11,172 & 3,29347 & \multirow{3}{*}{4,937} & \multirow{3}{*}{,008 } & \multirow{3}{*}{$\begin{array}{c}\text { Büyük>Küçük } \\
\text { Orta>Küçük }\end{array}$} \\
\hline & & Orta & 187 & 11,048 & 3,61788 & & & \\
\hline & & Küçük & 36 & 9,111 & 3,31040 & & & \\
\hline \multirow{3}{*}{\multicolumn{2}{|c|}{ Yaşam doyum }} & Büyük & 58 & 23,276 & 6,10663 & \multirow{3}{*}{2,564} & \multirow{3}{*}{,079 } & \\
\hline & & Orta & 187 & 22,594 & 6,72626 & & & \\
\hline & & Küçük & 36 & 20,222 & 6,52954 & & & \\
\hline
\end{tabular}

Öğrencilerin Facebook bağlanma stratejileri ölçeğinden aldıkları puanlara bakıldığında ölçeğin sadece "Bilgi arama" alt boyutundan aldıkları puanlar $\left[\mathrm{F}_{(2,278)}=4,937 ; p<0,05\right]$ arasında gruplar açısından istatistiksel olarak anlamlı bir farklılı̆̆ın olduğu görülmektedir (Tablo 10). Facebook bağlanma stratejileri ölçeğinin "Bilgi arama" alt boyutunda temel etkinin hangi değişkenden geldiğini belirlemek amacıyla Scheffe testi uygulanmıştır. Scheffe testi sonuçlarına göre, Facebook bağlanma stratejileri ölçeğinin "Bilgi arama" alt boyutunda çıkan farkın geldiği şehrin büyüklüğü "Büyük" olan öğrenciler ile geldiği şehrin büyüklüğü "Küçük" ve geldiği şehrin büyüklüğü "Orta" olan öğrenciler ile geldiği şehrin büyüklüğü "Küçük" olan öğrencilerden kaynaklandığg görülmektedir. Bu sonuca göre geldiği şehrin büyüklüğü "Büyük" veya "Orta" olan öğrencilerin geldiği şehrin büyüklüğü "Küçük" olan öğrencilere göre Facebook'u diğer insanlar hakkında bilgi edinmek amacıyla daha fazla kullandığını göstermektedir.

Öğrencilerin yaşam doyum puanlarına $\left[\mathrm{F}_{(2,278)}=2,564 ; p>0,05\right]$ bakıldığında ise gruplar açısından yaşam doyum puanları arasında istatistiksel olarak anlamlı bir fark yoktur (Tablo 10).

\section{Tartışma ve Sonuç}

İnternetin ortaya çıkmasıyla birlikte insanların iletişim biçimlerinde ve günlük yaşantılarında değişiklikler olmaya başlamıştır. Daha önce hiç bir şekilde internetle ilişkisi olmamış bireyler, ortaya yeni çıkan uygulamalar sayesinde internetle tanışmaktadır. Bu uygulamaların en önemlilerinden biri de sosyal ağ siteleridir. Kurulduğu günden beri bireylerin birbirleriyle iletişime geçmesini ve bağlantılı kalmasını sağlayan Facebook, sağlamış olduğu birçok yenilik sayesinde geniş kitleler tarafindan kabul görmüş bir sosyal ağ sitesidir. Sosyal etkileşim, iletişim ve bilgi edinme için tercih edilen bir ortam haline gelen Facebook, üniversite öğrencileri tarafindan giderek daha yaygın bir biçimde kullanılmaktadır (Wang, Moon, Kwon, Evans ve Stefanone, 2010; West, Lewis ve Currie, 2009). Biz de bu araştırmada üniversite öğrencilerinin Facebook bağlanma stratejileri ve yaşam doyumlarını çeşitli değişkenlere göre incelemeyi hedefledik. Bu amaçla öncelikle üniversite öğrencilerinin Facebook bağlanma stratejileri ile yaşam doyumları arasında bir ilişkinin var olup olmadığını, daha sonra da Facebook bağlanma stratejileri ve yaşam doyumlarını cinsiyet, öğrenim gördükleri okul türü, bilgisayar sahipliği, internet sahipliği, Facebook kullanım süresi, barınma türü ve geldiği şehir değişkenlerine göre farklılaşma durumlarını araştırdık.

İlk olarak, öğrencilerin Facebook'un farklı kullanımları (başlatma, sürdürme ve bilgi arama) ile yaşam doyumları arasında bir ilişkinin olduğunu ve öğrencilerin Facebook'u bu amaçlar (başlatma, sürdürme ve bilgi arama) için kullanımlarının artması ile yaşam doyumlarının da arttığını bulmuştuk. Bir kişinin yaşam doyumu, onun arkadaşları ile olan 
ilişkileri (Leary ve Kowalski, 1990), sosyal ve dışadönük kişiliği (Francis, 1999) ve aile bireylerinin mutluluğu (Clore, Wyer, Dienes, Gasper ve Isbell, 2001) ile yakından ilişkilidir. Dolayısıyla günümüzde aile ve arkadaşılı ilişkilerinin sosyal ağlar aracılığıyla daha da genişletildiği düşünüldüğünde, aktif olarak Facebook'a katılan ve kullanan bireylerin bu bağlantılılığ tecrübe etmesi kendisini daha mutlu hissetmesini sağlayabilir (Valkenburg, Peter ve Schouten, 2006). Ayrıca kişisel memnuniyet ile sosyal ağ siteleri arasındaki ilişkinin de karş1l1klı olduğu söylenebilir (Valenzuela, Park ve Kee, 2009). Örneğin, yaşam doyumu düşük olan üniversite öğrencileri kendi mutluluklarını artırmak için online ağlara katılmak isteyebilirler (Ellison, Steinfield ve Lampe, 2007). Johnston, Tanner, Lalla ve Kawalski'nin (2013) yaptıkları bir araştırmada Facebook kullanım yoğunluğu düşük seviyelerde olan öğrenciler üniversite yaşamları ile ilgili düşük doyum rapor etmişlerdir. Valenzuela, Park ve Kee (2009) Amerika Birleşik Devletleri'nin Teksas eyaletinde öğrenim gören 2603 üniversite öğrencisi ile yürüttükleri bir çalışmanın sonucunda öğrencilerin Facebook kullanım yoğunluğu ile yaşam doyumları arasında pozitif yönde ve orta düzeyde bir ilişki bulmuşlardır. Yapılan bu araştırma ve alanyazından da görüldügüü gibi, bireylerin Facebook'a giriş ve kullanım amaçları onların yaşam doyumları hakkında bilgi verebilir. Örneğin herhangi bir topluluğa (eğitim, sosyal kulüp vs.) ait olmak isteyen bir üniversite öğrencisi, bu nedenle Facebook'u bir araç olarak kullanabilir. Böylece bir topluluğa ait olma hissinden dolayı yaşam doyumu artabilir.

İkinci olarak, erkek öğrencilerin kız öğrencilere göre Facebook'u yeni insanlarla tanışma ve yakın arkadaşlıkları sürdürme amaçlı daha fazla kullandıklarını bulmuştuk. Kişilerin demografik bilgileri, özellikle de cinsiyet ile Facebook kullanım amacı arasında ilişki söz konusudur (Yaşar, 2015). Sheldon (2008) yaptığı bir çalışmada kız öğrencilerin Facebook'u daha çok var olan arkadaşlıklarını sürdürmek için kullandıklarını erkek öğrencilerin ise Facebook'u daha çok yeni arkadaşlıklar edinmek için kullandıklarını tespit etmiştir. Benzer şekilde Hargittai ve Hsieh (2010) de sosyal a ̆ sitelerindeki zayıf bağ (yeni insanlarla tanışma gibi) ve güçlü bağ (mevcut arkadaşlarla olan ilişkiyi sürdürme gibi) etkinliklerinin yordayıcılarını ve getirdiği sonuçlarını araştırdıkları çalışmalarında, kadınların erkeklere göre güçlü bağ etkinlikleri ile daha çok ilgilendiğini, bunun aksine erkeklerin de kadınlara göre zayıf bağ etkinlikleri ile daha çok ilgilendiklerini bulmuşlardır. McAndrew ve Jeong (2012) tarafından yapılan çalışmada, kadınların Facebook'ta erkeklere göre çok daha fazla vakit geçirdiği, daha fazla Facebook arkadaşına sahip olduğu ve kadınların profil resimlerini etki yönetimi amacıyla kullandıkları görülmüştür. Benzer şekilde Öztürk (2011) de üniversite öğrencileri ile yürüttüğü bir çalışmada kız öğrencilerin erkek öğrencilere göre Facebook'u sosyal ilişkiler amacıyla daha çok kullandığını, erkek öğrencilerin ise kız öğrencilere göre Facebook'u ders çalışma amacıyla daha çok kullandığını bulmuştur. Çelik (2013) ise Facebook üyeliği bulunan 1066 ögretmen adayı ile yürüttüğü çalışmada erkek öğretmen adaylarının kız öğretmen adaylarına göre Facebook'u sosyal ilişkiler için daha çok kullandıklarını bulmuştur. Kayri ve Çakır'ın (2010) yaptıkları bir çalışmada ise Facebook Kullanım amaçlarının (sosyal ilişkiler, çalışmalara ilişkin ve günlük kullanım) cinsiyete göre farklılık göstermediği bulunmuştur. Diğer yandan cinsiyet açısından erkek ve kız öğrencilerin yaşam doyumları arasında anlamlı bir farklılık bulunamamıştı. Valenzuela, Park ve Kee (2009), yaptıkları bir araştırmada bizim çalışmamıza benzer şekilde Facebook kullanan üniversite öğrencilerinin yaşam doyumlarının öğrencilerin cinsiyetleri açısından anlamlı derecede farklılaşmadığ 1 sonucuna ulaşmışlardır. Benzer şekilde Gündoğar, Sallan Gül, Uskun, Demirci ve Keçeci (2007) ve Chow (2007) üniversite öğrencilerinin yaşam doyumlarını araştırdıkları çalışmalarında kız ve erkek öğrencilerin yaşam doyumlarında anlamlı bir farklılık bulamamışlardır. Tuzgöl Dost (2007) ise yaptığı bir çalışmada, üniversite öğrencilerinin yaşam doyumlarında cinsiyet açısından kız öğrenciler lehine anlamlı bir farklılık bulmuştur. Yapılan önceki çalışmalardan da anlaşılacağı gibi cinsiyet, bireylerin Facebook kullanımlarında önemli bir değişkendir. Kız ve erkek üniversite öğrencilerinin Facebook'a bağlanma stratejileri farklılık göstermektedir. Bu konuyla ilgili farklı kültürlerden aynı cinsiyete sahip bireylerin Facebook kullanım amaçlarının incelenmesi alanyazına katkı sağlayabilir. 
Üçüncü olarak, üniversitenin meslek yüksekokullarında öğrenim gören öğrencilerin fakültelerinde öğrenim gören öğrencilere göre Facebook'u yeni insanlarla tanışmak (Başlatma), yakın arkadaşlıkları sürdürmek (Sürdürme) ve diğer insanlar hakkında daha fazla bilgi edinmek (Bilgi arama) amacıyla daha fazla kullandığını bulmuştuk. Çam (2012), yaptığı çalışmada Eğitim fakültelerinin farklı öğretmenlik programlarında öğrenim gören öğretmen adaylarının Facebook kullanım amaçlarının (sosyal ilişkiler, çalışmalara ilişkin ve günlük etkinlikler) öğrenim gördükleri öğretmenlik programına göre değişkenlik gösterdiğini belirtmektedir. Öztürk (2011) ise yaptı̆̆ı çalışmada öğrencilerin Facebook kullanım amaçlarının (Sosyal ilişkiler, çalışmalara ilişkin ve günlük etkinlikler) öğrenim gördükleri lisans programına göre sadece günlük etkinlikler alt amacında farklılık gösterdiğini tespit etmiştir. Diğer yandan üniversitenin meslek yüksekokullarında öğrenim gören öğrencilerin yaşam doyumlarının fakültelerinde öğrenim gören öğrencilere göre daha yüksek olduğunu bulmuştuk. Bu bulgu, üniversitenin meslek yüksekokullarında öğrenim gören öğrencilerin fakültelerinde öğrenim gören öğrencilere göre Facebook'u farklı amaçlar (Başlatma, sürdürme ve bilgi arama) için daha fazla kullandığg bulgusuyla birlikte düşünüldügünde, çalışmamızın bulgularından öğrencilerin Facebook'u farklı amaçlar (başlatma, sürdürme ve bilgi arama) için kullanımlarının artmasıyla yaşam doyumlarının da artması bulgusunu destekler niteliktedir. $\mathrm{Bu}$ araştırmanın bulguları göstermektedir ki, üniversite öğrencilerinin öğrenim gördükleri alana ek olarak, onların öğrenim düzeyinin de (önlisans ya da lisans) Facebook kullanım şekillerini etkilediği söylenebilir.

Dördüncü olarak, bilgisayarı ve interneti olan öğrencilerin bilgisayarı ve internet bağlantısı olmayan öğrencilere göre Facebook'u yeni insanlarla tanışmak (Başlatma), yakın arkadaşlıkları sürdürmek (Sürdürme) ve diğer insanlar hakkında daha fazla bilgi edinmek (Bilgi arama) amacıyla daha fazla kullandığını bulmuştuk. Çelik (2013), yaptığı çalışmada kişisel bir bilgisayarı ve internet bağlantısı olan öğretmen adayının, bilgisayarı ve internet bağlantısı olmayan öğretmen adayına göre Facebook'u diğer amaçlarının yanında çalışmalara ilişkin ve gündemdeki yenilikleri takip amaçlı daha çok kullanacağını iddia etmektedir. Diğer yandan bilgisayarı olan öğrencilerin yaşam doyumlarının bilgisayarı olmayan öğrencilerin yaşam doyumlarından daha yüksek olduğunu ve internet sahipliği açısından ise öğrencilerin yaşam doyumlarında anlamlı bir fark olmadığını bulmuştuk. Mevcut araştırmalar bireylerin yaşam doyumunun kısmen sosyal bağlarla belirlendiğinin altını çizmektedirler (Kahneman ve Krueger, 2006). Bireylerarası ilişkilerin ve sosyal etkileşimin niteliğinin zayıf olmasının yaratığı ruh halinin bireylerde yalnızlık duygusuna neden olduğu düşünüldügünde, kişilerin sahip oldukları yalnızlık duyguları, onların yaşamdan aldıkları doyumu yani yaşam doyumlarıyla ilişkilendirilebilir (Yılmaz ve Altınok, 2009). Yalnızlık ile yaşam doyum arasında ters yönde bir ilişkinin olduğu birçok araştırmacı tarafından raporlanmıştır (Goodwin, Cook ve Yung, 2001; Tuzgöl Dost, 2007; Yılmaz ve Altınok, 2009). Yalaz Seçim, Alpar ve Algür (2014) yaptıkları bir araştırmada kendine ait bilgisayarı ve interneti olan öğrencilerin olmayan öğrencilere göre kendilerini daha yalnız hissettiklerini bulmuşlardır. Yalnızlık ile yaşam doyum arasında ters yönde bir ilişkinin olduğu düşünüldügünde bu sonuç kendine ait bilgisayarı ve interneti olan öğrencilerin yaşam doyumlarının olmayan öğrencilere göre daha düşük olduğu şeklinde yorumlanabilir. Bizim bulgumuzla çelişen bu durum gelecekte yapılacak başka araştırmalarla konunun desteklenmesi gerektiğini göstermektedir.

Beşinci olarak, Facebook'u günde 1 saatten fazla kullanan öğrencilerin günde 1 saatten az kullanan öğrencilere göre Facebook'u yeni insanlarla tanışmak (Başlatma), yakın arkadaşlıkları sürdürmek (Sürdürme) ve diğer insanlar hakkında daha fazla bilgi edinmek (Bilgi arama) amacıyla daha fazla kullandığını bulmuştuk. Kayri ve Çakır (2010) yaptıkları bir çalışmada üniversite öğrencilerinin günlük Facebook kullanım süreleri arttıkça Facebook kullanım amacı (Sosyal ilişkiler, çalışmalara ilişkin ve günlük kullanım) puanlarının da arttı̆̆ını bulmuşlardır. Bundan farklı olarak Öztürk (2011) ise üniversite öğrencilerinin Facebook kullanım amaçlarının (sosyal ilişkiler, çalışmalara ilişkin ve günlük etkinlikler) Facebook kullanım süresine göre Facebook'u günlük 1 saatten az kullanan öğrenciler lehine farklılık gösterdiğini tespit etmiştir. Diğer yandan Facebook'u günde 1 saatten fazla kullanan 
öğrencilerin yaşam doyumlarının Facebook'u günde 1 saatten az kullanan öğrencilerin yaşam doyumlarından daha yüksek olduğunu göstermektedir. Valenzuela, Park ve Kee (2009) yaptıkları bir çalışmada üniversite öğrencilerinin Facebook kullanım yoğunluğunun artmasıyla yaşam doyumlarının da arttığı sonucuna ulaşmışlardır. Benzer şekilde Ellison, Steinfield ve Lampe (2007) de düşük yaşam doyumuna sahip üniversite öğrencilerinin yaşam doyumlarını arttırmak için çevrimiçi ağlara katılmayı isteyebileceklerini ifade etmektedirler. Yani kısacası, paylaştığı bir gönderinin beğenildiğini gören, kendi ilgi alanına uygun herhangi bir bilgi öğrenip bununla ilgili yorumlar yapan, uzun zamandır görüşmediği bir arkadaşını Facebook'ta bulup konuşmaya başlayan bir üniversite öğrencisinin Facebook'ta geçirdiği süre de artacaktır. Bu gibi nedenlerle bireyin Facebook'ta geçirdiği sürenin kendisini mutlu hissetmesine neden olduğu düşünüldüğünde, Facebook kullanım süresinin artmasıyla yaşam doyumun da artacağı söylenebilir.

Altıncı olarak, arkadaşı ile birlikte veya yurtta kalan öğrencilerin ailesi ile birlikte kalan öğrencilere göre Facebook'u yeni insanlarla tanışmak ve bir ilişkiyi başlatmak (Başlatma) için daha fazla kullandığını bulmuştuk. Hargittai ve Hsieh (2010), sosyal ağ sitelerindeki zayıf bağ (yeni insanlarla tanışma gibi) ve güçlü bağ (mevcut arkadaşlarla olan ilişkiyi sürdürme gibi) etkinliklerinin yordayıcılarını ve getirdiğgi sonuçlarını araştırdıkları çalışmalarında aileleri ile birlikte yaşamayanların aileleri ile birlikte yaşayanlara göre güçlü bağ etkinlikleri ile daha çok ilgilendiğini, zayıf bağ etkinliklerinde ise bu iki grup arasında anlamlı bir farklılığın olmadığını bulmuşlardır. Benzer şekilde Johnston ve diğerleri (2011) da Facebook'un Güney Afrika'da öğrenim gören üniversite öğrencilerinin sosyal sermaye oluşturmaları veya sürdürmeleri üzerindeki rolünü araştırdıkları araştırmalarında üniversite yurdunda kalmanın köprü kuran sosyal sermayenin (bireyler arasındaki sıradan tanışıklıkları ve yüzeysel ilişkileri içeren zayıf bağlar) anlamlı bir yordayıcısı olduğunu bulmuşlardır. Sonuç olarak, arkadaşları ile birlikte veya yurtta kalan öğrencilerin Facebook'u yeni insanlarla tanışmak ve bir ilişkiyi başlatmak için daha fazla kullanması, onların aile sosyal desteğinden yoksun olmaları ve bu boşluğu yeni arkadaşlık arayışları ile gidermeye çalıştıkları şeklinde yorumlanabilir. Diğer yandan öğrencilerin barınma türü açısından yaşam doyumlarında istatistiksel olarak anlamlı bir fark bulunamamıştı. Özgür, Babacan Gümüş ve Durdu (2010)'un 100'ü evde, 100'ü yurtta kalan toplam 200 üniversite öğrencisi ile yürüttükleri bir çalışmada araştırmaya katılan öğrencilerin yaşam doyumunu, evde ve yurtta kalmaya bağlı olarak değerlendirilmiş̧lerdir. Çalışma sonucunda evde kalan öğrencilerin yaşam doyumu yurtta kalan öğrencilerin yaşam doyumundan daha yüksek bulunmuştur.

Yedinci ve son olarak, geldiği şehrin büyüklügü "Büyük" veya "Orta” olan öğrencilerin geldiği şehrin büyüklüğü "Küçük" olan öğrencilere göre Facebook'u diğer insanlar hakkında daha fazla bilgi edinmek (Bilgi arama) amacıyla daha fazla kullandığı bulunmuştu. Bu durum daha büyük şehirlerden gelen üniversite öğrencileri yaşadığı sosyal çevre ve mekânlarla alakalı bilgi arama için Facebook'u bir araç olarak görmesinden kaynaklanıyor olabilir. Öztürk'ün (2011) yaptığı bir çalışmada öğrencilerin Facebook kullanım amaçlarının (Sosyal ilişkiler, çalışmalara ilişkin ve günlük etkinlikler) öğrencilerin doğduğu yerlere göre sadece günlük etkinlikler alt amacında farklılık gösterdiği tespit edilmiştir. Buna göre köyde doğan üniversite öğrencilerinin sosyal paylaşım sitelerini "günlük kullanım" amacıyla daha çok kullandıklarını göstermektedir. Diğer yandan öğrencilerin geldiği şehrin büyüklüğü açısından yaşam doyumlarında istatistiksel olarak anlamlı bir fark bulunamamıştı. Özgür, Babacan Gümüş ve Durdu'un (2010) evde ve yurtta kalan üniversite öğrencilerinin yaşam doyumlarını araştırdıkları bir çalışmalarında, evde ve yurtta kalan üniversite öğrencilerinin yaşam doyumlarında en uzun süre yaşadıkları yerin büyüklüğ̈ açısından istatistiksel olarak anlamlı bir farklılık bulunamamıştır. Ancak, Valenzuela, Park ve Kee (2009) ise Amerika Birleşik Devletleri'nin Teksas eyaletinde öğrenim gören 2603 üniversite öğrencisi ile yürüttükleri bir çalışmanın sonucunda memleketi Teksas olan öğrencilerin yaşam doyumlarının diğer öğrencilere göre daha yüksek olduğunu bulmuşlardır. 


\section{Öneriler}

$\mathrm{Bu}$ çalışma, üniversite öğrencileri tarafindan sıklıkla kullanılan sosyal ağ sitelerinden biri olan Facebook hakkında bir bakış sağlamaktadır. Çalışmada, öncelikle üniversite öğrencilerinin Facebook'a bağlanma biçimleri ile yaşam doyumları arasındaki ilişkiler araştırılmıştır. Daha sonra sadece belirli değişkenlere göre (cinsiyet, okul türü, bilgisayar sahipliği, internet sahipliği, Facebook kullanım süresi, barınma türü ve geldiği şehir) üniversite öğrencilerinin Facebook’a bağlanma biçimleri ile yaşam doyumları incelenmiştir. İleriki çalışmalar farklı demografik değişkenlerle bu bağımlı değişkenleri (Facebook bağlanma stratejileri ve yaşam doyum) veya sosyal sermaye, sosyal güven, akademik başarı, yalnızlık, problemli internet kullanımı gibi başka bağımlı değişkenleri de dikkate alarak araştırabilirler. Bunun yanı sıra bu çalışmanın örneklem büyüklügüü ve yöntem açısında bazı sınırlılıklara sahip olduğu söylenebilir. İlk olarak, bu çalışmanın ve gelecekteki çalışmaların sonuçlarını daha genellenebilir yapmak için başka örneklem grupları çalışmaya dâhil edilebilir. İkinci olarak bu çalışmanın verileri bireylerin kendilerini değerlendirmelerine dayalı olduğu için anketlere verilen cevaplar katılımcıların kendilerini dürüstçe değerlendirmek için istekli olmaları ve güvenilir hatırlama kabiliyetleri ile sinırlıdır. Üçüncü ve son olarak bu çalışmada zaman içindeki tek bir noktadaki algılar ölçüldüğü için üniversite öğrencilerinin zamanla algılarının değişebileceği göz önünde bulundurulmalıdır.

\section{Kaynaklar}

Acquisti, A. ve Gross, R. (2006). Imagined communities: Awareness, information sharing, and privacy on the Facebook. P. Golle ve G. Danezis (Yay. haz.). Proceedings of $6^{\text {th }}$ Workshop on Privacy Enhancing Technologies içinde (ss. 36-58), Cambridge, UK: Robinson College.

Aktürk, A. O., Çelik, İ., Şahin, İ. ve Deniz, M. E. (2014). Facebook bağlanma stratejileri ölçeğinin Türkçe uyarlama çalışması, İlkögretim Online, 13(1), 319-333.

Aktürk, A. O., Şahin, İ. ve Sünbül, A. M. (2008). Bilgisayar Öğretmen Adaylarının Web Temelli Öğretim Hakkındakı Görüşleri. g $^{\text {th }}$ International Educational Technology Conference. Eskişehir: Anadolu University, May 06-09, 2008, 855-861.

Boyd, D. M. ve Ellison, N. B. (2007). Social network sites: Definition, history, and scholarship. Journal of Computer-Mediated Communication, 13(1), Erişim adresi: http://jcmc.indiana.edu/ vol13/issue1/boyd.ellison.html

Çam, E. (2012). Öğretmen adaylarının eğitsel ve genel amaçlı Facebook kullanımları ve Facebook bağımlılıkları (SÄ̈ Ĕgitim Fakültesi Örneği). (Yayımlanmamış yüksek lisans tezi). Sakarya Üniversitesi, Sakarya.

Can, F. (2009). Yakın ilişsilerde sosyal ă̆ın ilişski nitelikleri ile bağlantısı. (Yayımlanmamış yüksek lisans tezi), Ankara Üniversitesi, Ankara.

Çelik, İ. (2012). Öğretmen adaylarının sosyal ă̆ (Facebook) kullanımlarının incelenmesi. (Yayımlanmamış yüksek lisans tezi), Necmettin Erbakan Üniversitesi, Konya.

Chow, H. P. (2005). Life satisfaction among university students in a Canadian prairie city: A multivariate analysis. Social Indicators Research, 70(2), 139-150.

Clore, G. L., Wyer, R. S., Jr., Dienes, B., Gasper, K. ve Isbell, L. M. (2001). Affective feelings as feedback: Some cognitive consequences. L. L. Martin ve G. L. Clore (Yay. haz.), Theories of mood and cognition: A user's guidebook içinde (ss. 27-62). Hillsdale, NJ: Erlbaum.

Cochrane, T. D. (2014). Critical success factors for transforming pedagogy with mobile Web 2.0. British Journal of Educational Technology, 45(1), 65-82.

Coyle, C. L. ve Vaughn, H. (2008) Social networking: Communication revolution or evolution? Bell Labs Technical Journal, 13(2), 13-18.

D'souza, Q. (2006). Web 2.0 Ideas for educators a guide to RSS and more. Erişim adresi: http://www.teachinghacks.com/audio/100ideasWeb2educators.pdf

Diener, E., Emmons, R. A., Laresen, R. J. ve Griffin, S. (1985). The satisfaction with life scale. Journal of Personality Assessment, 49(1), 71-75. 
Dietrich, J., Jones, N. ve Wright, J. (2008). Using social networking and semantic web technology in software engineering-Use cases, patterns, and a case study. Journal of Systems and Software, 81(12), 2183-2193.

Echeng, R. ve Usoro, A. (2017). E-learning implementation issues and strategies to address low participation using an enhanced model of acceptance of web 2.0 technologies: A case study of a scottish university. International Journal on E-Learning, 16(1), 5-22.

Ellison, N. B., Steinfield, C. ve Lampe, C. (2007). The benefits of Facebook "Friends": social capital and college students' use of online social network sites. Journal of ComputerMediated Communication, 12, 1143-1168.

Ellison, N. B., Steinfield, C. ve Lampe, C. (2011). Connection strategies: Social capital implications of Facebook-enabled communication practices. New Media \& Society, 13(6), 873-892.

Erkoç, M. F. ve Erkoç, Ç. (2011). Değerler Eğitiminde Etkinlik Ortamı Olarak Sosyal Ağ Sitelerinin Kullanımı: Facebook Gruplar1. $5^{\text {th }}$ International Computer \& Instructional Technologies Symposium. Elazığ: Firat University. 22-24 September 2011, 203-208.

Facebook (2017). Facebook Türkçe ana sayfa. Erişim adresi: https://tr-tr.facebook.com

Feng, S., Wang, D., Yu, G., Gao, W. ve Wong, K. F. (2011). Extracting common emotions from blogs based on fine-grained sentiment clustering. Knowledge and information systems, 27(2), 281-302.

Francis, L. J. (1999). Happiness is a thing called stable extraversion: A further examination of the relationship between the Oxford Happiness Inventory and Eysenck's dimensional model of personality and gender. Personality and Individual Differences, 26, 5-11.

Goodwin, R., Cook, O. ve Yung, Y. (2001). Loneliness and life satisfaction among three cultural groups. Personal Relationships, 8(2), 225-230.

Govani, T. ve Pashley, H. (2005). Student awareness of the privacy implications when using Facebook. Unpublished paper presented at the "Privacy Poster Fair" at the Carnegie Mellon University School of Library and Information Science, 9, 1-17.

Gündoğar, D., Sallan Gül, S., Uskun, E., Demirci, S. ve Keçeci, D. (2007). Üniversite ögrencilerinde yaşam doyumunu yordayan etkenlerin incelenmesi. Klinik Psikiyatri, 10, 4-27.

Hargittai, E. ve Hsieh, Y.-L.P. (2010). Predictors and consequences of differentiated practices on Social Network Sites. Information, Communication \& Society, 13(4), 515-536.

Herbig, P. ve Hale, B. (1997). Internet: The marketing challenge of the twentieth century. Internet Research, 7(2), 95-100.

Huck, S. W. (2012). Reading statistics and research (6th ed.). Boston, MA: Pearson.

İşman, A. (2011). Öğretim teknolojileri ve materyal tasarımı. Ankara: Pegem Akademi.

Johnson, B. ve Christensen, L. (2000). Educational research quantitative and qualitative approaches. Boston, MA: Allyn and Bacon.

Johnston, K., Tanner, M., Lalla, N. ve Kawalski, D. (2013). Social capital: the benefit of Facebook 'friends'. Behaviour \& Information Technology, 32(1), 24-36.

Joy, P. ve Katherine, K. (2008). Social networking profiles: An examination of student attitudes regarding use and appropriateness of content. Cyber Psychology \& Behavior, 11(1), 95-97.

Kahneman, D. ve Krueger, A. B. (2006). Developments in the measurement of subjective wellbeing. Journal of Economic Perspectives, 20(1), 3-24.

Karahan, E. ve Roehrig, G. (2016). Use of Web 2.0 technologies to enhance learning experiences in alternative school settings. International Journal of Education in Mathematics, Science and Technology, 4(4), 272-283.

Karasar, N. (2006). Bilimsel araştırma yöntemleri. Ankara: Nobel Yayın Dağıtım.

Kayri, M. ve Çakır, Ö. (2010). An applied study on educational use of Facebook as a Web 2.0 tool: The sample lesson of computer networks and communication. International Journal of Computer Science \& Information Technology (IJCSIT), 2(4), 48-58. 
Kobak, K. ve Biçer, S. (2008). Facebook Sosyal Paylaşım Sitesinin Kullanım Nedenleri. $8^{\text {th }}$ International Educational Technology Conference. Eskișehir: Anadolu University, May 06-09, 2008, 567-571.

Koh-Herlong, L. ve Brown, A. (2017). Consider four types of online identities for teaching and modeling online behavior. Teacher Education for Ethical Professional Practice in the 21 st Century içinde (ss. 48-71). IGI Global.

Köker, S. (1991). Normal ve sorunlu ergenlerin yaşam doyumu düzeyinin karşılaştırılması. (Yayımlanmamış yüksek lisans tezi). Ankara Üniversitesi, Ankara.

Korkmaz, İ. (2012). Facebook ve mahremiyet: Görmek ve gözetle(n)mek. Yalova Sosyal Bilimler Dergisi, 5, 107-122.

Lai, L. S. ve To, W. M. (2015). Content analysis of social media: A grounded theory approach. Journal of Electronic Commerce Research, 16(2), 138-152.

Lampe, C., Ellison N. B. ve Steinfield, C. (2008). Changes in Use and Perception of Facebook. Proceedings of the 2008 ACM Conference on Computer Supported Cooperative Work (CSCW'08). CA: San Diego, November 8-12, 2008, 721-730.

Leary, M. R. ve Kowalski, R. M. (1990). Impression management: A literature review and twocomponent model. Psychological Bulletin, 107, 34-47.

Leech, N. L., Barrett, K. C. ve Morgan, G. A. (2005). SPSS for intermediate statistics: Use and interpretation. Mahwah, NJ: Lawrence Erlbaum Associates.

Lenhart, A. ve Madden, M. (2007). Social networking web sites and teens: An overview. Pew Internet and American Life Project Report.

Marshall, G. (1999). Sosyoloji sözlüğ̈̈. O. Akınhay ve D. Kömürcü (Çev.). İstanbul: Bilim ve Sanat Yayınları.

McAndrew, F. T. ve Jeong, H. S. (2012). Who does what on Facebook? Age, sex, and relationship status as predictors of Facebook use. Computers in Human Behavior, 28(6), 2359-2365.

O'Reilly, T. (2005). What is Web 2.0: Design patterns and business models for the next generation of software. Erişişm adresi: http://oreilly.com/web2/archive/what-is-web20.html

Orenga-Roglá, S. ve Chalmeta, R. (2016). Social customer relationship management: Taking advantage of Web 2.0 and Big Data technologies. SpringerPlus, 5(1), 1462-1479.

Özer, M. ve Karabulut, Ö. Ö. (2003). Yaşlilarda yaşam doyumu. Geriatri, 6(2), 72-74.

Özgür, G., Babacan Gümüş, A. ve Durdu, B. (2010). Evde ve yurtta kalan üniversite öğrencilerinde yaşam doyumu. Psikiyatri Hemşireliği Dergisi, 1(1), 25-26.

Özmen, F., Aküzüm, C., Sünkür, M. ve Baysal, N. (2012). Sosyal ağ sitelerinin eğitsel ortamlardaki işlevselliği. NWSA: Education Sciences, 7(2), 496-506.

Öztürk, M. (2011). Üniversite ögrencilerinin sosyal paylaşım sitelerini kullanma amaçları ve eğitimde kullanımıyla ilgili görüşleri (Yayımlanmamış yüksek lisans tezi). Sakarya Üniversitesi, Sakarya.

Pavot, W., Diener, E. D., Colvin, C. R. ve Sandvik, E. (1991). Further validation of the satisfaction with life scale: Evidence for the cross-method convergence of well-being measures. Journal of Personality Assessment, 57(1), 149-161.

Rheingold, H. (2000). Virtual community: Homesteading on the electronic frontier. Cambridge: MIT Press.

Scheufele, D. A. ve Shah, D. V. (2000). Personality strength and social capital: The role of dispositional and informational variables in the production of civic participation. Communication Research, 27, 107-131.

Şener, G. (2009). Türkiye'de Facebook Kullanımı Araştırması. XIV. Türkiye'de Internet Konferanst. İstanbul: Bilgi Üniversitesi, 12-13 Aralık 2009, 33-41.

Sheldon, P. (2008). Student favourite: Facebook and motives for its use. Southwestern Mass Communication Journal, 23(2), 39-53.

Socialbakers (2017a). Facebook statistics directory. Erişim adresi: https://www.socialbakers.com/statistics/facebook/ 
Socialbakers (2017b). December 2016 Social Marketing Report Turkey. Erişim adresi: https://www.socialbakers.com/resources/reports/turkey/2016/december/

Topkaya, N. ve Kavas, A. B. (2015). Algılanan sosyal destek, yaşam doyumu, psikolojik yardım almaya ilişkin tutum ve niyet arasındaki ilişkiler: Bir model çalışması. International Periodical For The Languages, Literature and History of Turkish, 10(2), 979-996.

Tuzgöl Dost, M. (2007). Üniversite öğrencilerinin yaşam doyumunun bazı değişkenlere göre incelenmesi. Pamukkale Üniversitesi Eğitim Fakültesi Dergisi, 22, 132-143.

Uslu Karahan, Z. (2007). Yeni iletişim araçları ve toplumsal etkileri. Sosyoloji Araştırmaları Dergisi, 10(1), 224-234.

Valenzuela, S., Park, N. ve Kee, K. F. (2009). Is there social capital in a social network site?: Facebook use and college students' life satisfaction, trust, and participation. Journal of Computer-Mediated Communication, 14, 875-901.

Valkenburg, P. M., Peter, J. ve Schouten, A. P. (2006). Friend networking sites and their relationship to adolescents' well-being and social self-esteem. Cyber Psychology \& Behavior, 9, 584-590.

Wang, S. S., Moon, S., Kwon, K. H., Evans, C. A. ve Stefanone, M. A. (2010). Face off: Implications of visual cues on initiating friendship on facebook. Computers in Human Behaviour, 26(2), 226-234.

Warschauer, M. ve Grimes, D. (2007). Audience, authorship, and artifact: The emergent semiotics of Web 2.0. Annual Review of Applied Linguistics, 27, 1-23.

West, A., Lewis, J. ve Currie, P. (2009). Students' Facebook 'friends': Public and private spheres. Journal of Youth Studies, 12(6), 615-627.

Yalaz Seçim, Ö., Alpar, Ö. ve Algür, S. (2014). Üniversite öğrencilerinde yalnızlık: Akdeniz Üniversitesi'nde yapılan ampirik bir araştırma. Elektronik Sosyal Bilimler Dergisi, 13(48), 200-215.

Yaşar, N. N. (2015). Türkiye'deki bireylerin kişilik özellikleri, Facebook kullanımları ve boş zaman aktiveleri (Yayımlanmamış yüksek lisans tezi). İstanbul Teknik Üniversitesi, İstanbul.

Yılmaz, E. ve Altınok, V. (2009). Okul yöneticilerinin yalnızlık ve yaşam doyum düzeylerinin incelenmesi. Kuram ve Uygulamada Eğitim Yönetimi, 15(59), 451-469.

\section{Extended Abstract \\ Introduction}

Together with the rapidly developing technology, the innovations in the communication habits of humans have caused a rapid change also in their attitudes of socialization. Socializing habits of individuals started to show fundamental changes based upon the new technologies that walked into their lives and changed their domains for forming social environments (Erkoç \& Erkoç, 2011; Özmen, Aküzüm, Sünkür \& Baysal, 2012; Uslu Karahan, 2007). The Internet and the related technologies are the most important of these domains. The Internet moved to a whole new era with Web 2.0 tools which connect people to one another and increase their ability to access information (Warschauer \& Grimes, 2007). Individuals who had no involvement with the internet in any way before meeting the internet owing to the newly emerging Web 2.0 applications. One of the most important of these applications is social networks.

Although the term social network is mentioned with the Internet, the concept existed a very long time before our day, because humans are social beings and they need to get into contact with the others to maintain their lives (Coyle \& Vaughn, 2008). Besides being a set of technological tools that include the features of the technologies before them (such as personal websites), social networking sites reshape their users' skills of establishing and maintaining a wide social relationship network in a new context (Ellison, Steinfield \& Lampe, 2011). Today, the social networking site with the highest number of users is Facebook.com. Facebook enables people to "communicate with the people they know and share what is going on in their lives (Facebook, 2017). Undoubtedly, Facebook has also attracted the attention of researchers as the most popular social networking site of recent times whose number of users has been increasing 
rapidly. Because of this popularity of Facebook, researchers conducted various studies to understand why, to what extent, and how this social networking site is used.

One of the factors that affect the purposes, periods, and expectations of Facebook usage is the users' expectations from life (Valenzuela, Park \& Kee, 2009). It is considered that the level of individuals' quality of life and whether they sufficiently enjoy life is also affected by their use of social networks on the Internet. Other indicators of life satisfaction and quality of life reflect a person's ideas related his/her environments including either positive or negative ideas (Scheufele \& Shah, 2000). Current studies emphasize that the life satisfaction of individuals is determined by social connections in some measure (Kahneman \& Krueger, 2006; Valenzuela, Park \& Kee, 2009). Different from the others, in this study we aimed to examine the relationship between the Facebook connection strategies and life satisfaction of university students in the context of this social networking site that connects people to one another and causes a radical change in habits for forming their social environment. For this purpose, we first examined whether there was a relationship between the students' Facebook connection strategies and their life satisfaction, afterwards, we investigated the differences in Facebook connection strategies and life satisfaction with respect to the variables of gender, the type of school they attended, computer ownership, Internet ownership, duration of their Facebook use, housing type, and hometown.

\section{Method}

The relational survey model, which is one of the survey models, was used in the study aimed at describing the current situation. The study group consisted of 281 university students. "Facebook Connection Strategies Scale" was used to determine the Facebook connection strategies, and "Life Satisfaction Scale" was used to determine the life satisfaction levels of the students that participated in the study. Before the analysis of the data obtained from the study, it was tested whether the data showed a normal distribution. For this purpose, central distribution, skewness, and kurtosis values were examined over the distributions of the total scores obtained from the scales. In addition, the Kolmogorov-Smirnov Test implemented on the data revealed that the data showed normal distribution and it was decided to use parametric statistics. Accordingly, the analyses were conducted by using descriptive statistics and correlation analysis. Besides, the independent samples t-test was used to compare pair groups, whereas more than two groups were compared using the one-way analysis of variance (ANOVA). In the ANOVA test, the differences among the groups were examined by using the Scheffe test.

\section{Result and Discussion}

The findings obtained in the study showed that there was a positive significant relationship between the life satisfaction and Facebook connection strategies (initiating, maintaining and information-seeking) of the students. Furthermore, the results of the study showed that the Facebook connection strategies (initiating, maintaining and information-seeking) and life satisfaction of the students showed significant differences with respect to the variables of type of school they attended, computer ownership, and duration of their Facebook use. In addition, the Facebook connection strategies (initiating, maintaining and information-seeking) of the students showed significant differences with respect to the variables of gender (at the dimensions of initiating, maintaining and information-seeking), Internet ownership (at the dimensions of initiating, maintaining and information-seeking), housing type (at the dimension of initiating), and hometown (at the dimension of information-seeking). 